\title{
Growth and characterization of epitaxial Ti3GeC2 thin films on $4 \mathrm{H}-\mathrm{SiC}(0001)$
}

Kristina Buchholt, Per Eklund, Jens Jensen, Jun Lu, R Ghandi, M Domeij,

C M Zetterling, G Behan, H Zhang, Anita Lloyd Spetz and Lars Hultman

\section{Linköping University Post Print}

N.B.: When citing this work, cite the original article.

Original Publication:

Kristina Buchholt, Per Eklund, Jens Jensen, Jun Lu, R Ghandi, M Domeij, C M Zetterling, G Behan, H Zhang, Anita Lloyd Spetz and Lars Hultman, Growth and characterization of epitaxial Ti3GeC2 thin films on 4H-SiC(0001), 2012, Journal of Crystal Growth, (343), 1, 133-137.

http://dx.doi.org/10.1016/j.jcrysgro.2012.01.020

Copyright: Elsevier http://www.elsevier.com/

Postprint available at: Linköping University Electronic Press http://urn.kb.se/resolve?urn=urn:nbn:se:liu:diva-77103 


\title{
Growth and characterization of epitaxial $\mathrm{Ti}_{3} \mathrm{GeC}_{2}$ thin films on $4 \mathrm{H}-\mathrm{SiC}(0001)$
}

\author{
K. Buchholt ${ }^{\mathrm{a}}$, P. Eklund ${ }^{\mathrm{a}}$, J. Jensen ${ }^{\mathrm{a}}, \mathrm{J}_{\text {L Lu }}^{\mathrm{a}}$, R. Ghandi ${ }^{\mathrm{b}}$, M. Domeij ${ }^{\mathrm{b}}$, \\ C. M. Zetterling ${ }^{\mathrm{b}}$, G. Behan ${ }^{\mathrm{c}}, \mathrm{H}$. Zhang $^{\mathrm{c}}$, A. Lloyd Spetz ${ }^{\mathrm{a}}$, and \\ L. Hultman ${ }^{\mathrm{a}}$
}

a Department of Physics, Chemistry and Biology (IFM), Linköping University, SE-581 83 Linköping, Sweden

${ }^{\mathrm{b}}$ School of Information and Communication Technology, KTH, Royal Institute of Technology, Electrum 229, SE-164 40 Kista-Stockholm, Sweden

${ }^{\mathrm{c}}$ School of Physics and Centre for Research on Adaptive Nanostructures and Nanodevices (CRANN), Trinity College Dublin, Dublin 2, Republic of Ireland

* Corresponding author. E-mail: kribu@ifm.liu.se

\begin{abstract}
Epitaxial $\mathrm{Ti}_{3} \mathrm{GeC}_{2}$ thin films were deposited on $4^{\circ}$ off-cut $4 \mathrm{H}-\mathrm{SiC}(0001)$ using magnetron sputtering from high purity Ti, C, and Ge targets. Scanning electron microscopy and helium ion microscopy show that the $\mathrm{Ti}_{3} \mathrm{GeC}_{2}$ films grow by lateral step-flow with $\{11 \overline{2} 0\}$ faceting on the SiC surface. Using elastic recoil detection analysis, atomic force microscopy, and X-Ray diffraction the films were found to be substoichiometric in Ge with the presence of small Ge particles at the surface of the film.
\end{abstract}

Keywords A1. Surface structure, A1. Atomic force microscopy, A1. Helium ion microscopy, A3. Physical vapor deposition processes, B1. Titanium compound 


\section{Introduction}

The group of inherently nanolaminated ternary carbides and nitrides called MAX phases exhibits a unique combination of metallic and ceramic properties, and has attracted considerable interest since the 1990s when Barsoum et al. reported on the fabrication and characterization of $\mathrm{Ti}_{3} \mathrm{SiC}_{2}$ [1], and shortly thereafter $\mathrm{Ti}_{3} \mathrm{GeC}_{2}$ [2]. The MAX phases have the general chemical formula $\mathrm{M}_{n+1} \mathrm{AX}_{n}$ where $\mathrm{n}=1,2$, or 3, and $M$ is an early transition element, $A$ is an A-group element, and $X$ is $\mathrm{C}$ or N. For reviews on the topic, see references [3- 5].

$\mathrm{Ti}_{3} \mathrm{SiC}_{2}$ is known to form after high temperature annealing of $\mathrm{Ti}-$, and $\mathrm{Ti} / \mathrm{Al}-$ based contacts on $\mathrm{SiC}$ [6-10]. In recent publications, we have reported on the ohmic contact properties of sputter-deposited $\mathrm{Ti}_{3} \mathrm{SiC}_{2}$ on $4 \mathrm{H}-\mathrm{SiC}(0001)$, and investigated the step-flow growth mode of epitaxially grown $\mathrm{Ti}_{3} \mathrm{SiC}_{2}$ layers on $\mathrm{SiC}[11,12]$.

Ti-A-C MAX phase material systems related through their A-group elements from group 14 include Ti-Si-C, Ti-Ge-C, Ti-Sn-C, and Ti-Pb-C. These material systems display differences in phase distribution. The Ti-Si-C system contains the phases $\mathrm{Ti}_{3} \mathrm{SiC}_{2}$ and $\mathrm{Ti}_{4} \mathrm{SiC}_{3}$, where the former is the most studied member of the MAX phase family. In the Ti-Ge-C system, the 211,312 , and 413 phases $\mathrm{Ti}_{2} \mathrm{GeC}$, $\mathrm{Ti}_{3} \mathrm{GeC}_{2}$, and $\mathrm{Ti}_{4} \mathrm{GeC}_{3}$ have been epitaxially grown in thin-film form onto $\mathrm{Al}_{2} \mathrm{O}_{3}(0001)$ substrates using magnetron sputtering. Four-point probe measurements of the epitaxial Ti-Ge-C thin films show them to be good conductors, with conductivity values for $\mathrm{Ti}_{3} \mathrm{GeC}_{2}$ films comparable to those of $\mathrm{Ti}_{3} \mathrm{SiC}_{2}$ films [13]. Studies on the electronic transport properties of MAX phases using the model system $\mathrm{Ti}_{2} \mathrm{GeC}$ showed isotropic electronic transport behavior [14]. The Ti-Sn-C system 
contains the two phases $\mathrm{Ti}_{2} \mathrm{SnC}$ and $\mathrm{Ti}_{3} \mathrm{SnC}_{2}$ while in the $\mathrm{Ti}-\mathrm{Pb}-\mathrm{C}$ system the only known phase is $\mathrm{Ti}_{2} \mathrm{PbC}$. Resistivity values for magnetron sputtered $\mathrm{Ti}_{2} \mathrm{SnC}$ thin films have been reported to be three times higher than for $\mathrm{Ti}_{2} \mathrm{GeC}$ films, however, the crystalline quality was lower for the $\mathrm{Ti}_{2} \mathrm{SnC}$ films [15]. Resistivity values for $\mathrm{Ti}_{2} \mathrm{PbC}$ are not available in literature due to difficulty in fabricating samples pure enough for characterization [16], and the material has not been synthesized in thin film form.

Studies of $\mathrm{M}_{2} \mathrm{AlC}(\mathrm{M}=\mathrm{Ti}, \mathrm{V}, \mathrm{Cr})$ show that substitutions at the M-site leads to an increase in resistivity [17]. The same trend can be observed for $\mathrm{M}_{2} \mathrm{GeC}(\mathrm{M}=\mathrm{Ti}$, $\mathrm{V}, \mathrm{Cr}$ ) where the highest resistivity is reported for $\mathrm{Cr}_{2} \mathrm{GeC}$ films $[15,18,19]$. In the M-Ge-C system, the influence of M-site solid solutions on material properties has been studied for $(\mathrm{Ti}, \mathrm{V})_{n+1} \mathrm{GeC}_{n}[20]$ and $\left(\mathrm{Cr}_{1-x} \mathrm{~V}_{x}\right)_{2} \mathrm{GeC}$ [21] thin films.

The good conductivity values reported for Ti-Ge-C thin films make the material system interesting to study as a candidate for ohmic contact layer on $\mathrm{SiC}$. Investigating $\mathrm{Ti}_{3} \mathrm{GeC}_{2}$ provides an opportunity to study the influence of substituting $\mathrm{Si}$ (used in our previous studies of $\mathrm{Ti}_{3} \mathrm{SiC}_{2}$ ) with $\mathrm{Ge}$ in a $312 \mathrm{Ti}-\mathrm{A}-\mathrm{C}$ MAX phase.

Although $\mathrm{Ti}_{3} \mathrm{SiC}_{2}$ and $\mathrm{Ti}_{3} \mathrm{GeC}_{2}$ are isostructural phases with similar properties, they exhibit differences in thermal and mechanical properties [22] and the growth behavior of sputtered $\mathrm{Ti}_{3} \mathrm{GeC}_{2}$ thin films on $4 \mathrm{H}-\mathrm{SiC}$ is not known; nor are its electrical contact properties. Here, we investigate the epitaxial growth of $\mathrm{Ti}_{3} \mathrm{GeC}_{2}$ thin films on $4^{\circ}$ off-cut $4 \mathrm{H}-\mathrm{SiC}(0001)$ substrates using DC magnetron sputtering from three sources. We present results on a layer-by-layer growth mode of $\mathrm{Ti}_{3} \mathrm{GeC}_{2}$ on the stepped surface of $\mathrm{SiC}$ and discuss the similarities and differences to the related phase $\mathrm{Ti}_{3} \mathrm{SiC}_{2}$. 


\section{Experimental details}

A $4 \mathrm{H}$-SiC $n$-type wafer, Si-face, with a $4^{\circ}$ off-cut, from SiCrystal [23] was used as substrate. The wafer has a $1 \mu \mathrm{m}$ thick $p-\left(4 \times 10^{15} \mathrm{~cm}^{-3}\right)$ doped epitaxially grown $\mathrm{SiC}$ layer with a $0.8 \mu \mathrm{m} n$ - $\left(1.5 \times 10^{19} \mathrm{~cm}^{-3}\right)$ doped epitaxially grown $\mathrm{SiC}$ layer on top. The doping atoms used for the epilayers were $\mathrm{Al}$ and $\mathrm{N}$ for the $p$ - and $n$-type, respectively, and were grown at the Institute Acreo [24]. Prior to deposition the substrates were ultrasonically cleaned in acetone and isopropanol for 5 minutes each. The substrates were then blown dry in $\mathrm{N}_{2}$ gas and immediately loaded into the ultrahigh vacuum sputtering system. The substrates were heated to the deposition temperature of $800{ }^{\circ} \mathrm{C}$ and left to stabilize at that temperature for $1 \mathrm{~h}$ prior to deposition. Immediately before deposition the substrates were plasma etched for 30 minutes through operating the Ti-target at $25 \mathrm{~mA}$ in high purity Ar discharges, while applying a negative bias of $-50 \mathrm{~V}$ to the substrate, in order to remove any remaining surface oxide on the $\mathrm{SiC}$ substrate [12].

$\mathrm{Ti}_{3} \mathrm{GeC}_{2}$ films were grown by $\mathrm{DC}$ magnetron sputtering, using high purity $\mathrm{C}$, Ge, and Ti targets, using an experimental setup described elsewhere [25]. All depositions were performed at a constant pressure of $\sim 0.5 \mathrm{~Pa}$ in high purity $\mathrm{Ar}$ discharges. The magnetrons were operated in current-regulation mode, with the target currents fixed at $310 \mathrm{~mA}$ for $\mathrm{Ti}, 370 \mathrm{~mA}$ for $\mathrm{C}$, and $80 \mathrm{~mA}$ for the Ge target. The duration of the deposition was $1 \mathrm{~h}$, resulting in approximately $200 \mathrm{~nm}$ thick films.

The as-deposited films were characterized by $\theta-2 \theta$ X-ray diffraction (XRD) measurements, performed in a Philips PW 1820 diffractometer with $\mathrm{Cu}$ Ka radiation, operated at $40 \mathrm{kV}$ and $40 \mathrm{~mA}$. Alignment of the instrument using the (0004) $\mathrm{SiC}$ 
substrate peak gives an offset of $\sim 4^{\circ}$ due to the $4^{\circ}$ off-cut of the SiC substrate. Surface morphology was investigated using secondary-electron images from a Leo 1550 Gemini scanning electron microscope (SEM), using a $5 \mathrm{kV}$ accelerating voltage, and helium ion microscopy (HIM), using an ORION PLUS microscope from Carl Zeiss SMT. Plan-view images were obtained using $30 \mathrm{keV} \mathrm{He}^{+}$ions. The imaging was performed by detecting secondary electrons, using an Everhart-Thornley detector. Prior to observation the sample was plasma cleaned to remove hydrocarbons contamination on the sample surface. A Dimension 3100 atomic force microscopy (AFM), was also used to investigate surface morphology. Cross-sectional samples for transmission electron microscopy (TEM) using a Tecnai G2 TF20UT FEG, were prepared by gluing two pieces of thin film samples face to face and clamping them with a Ti grid. The sandwich-like specimen was polished to a thickness of about 50 $\mu \mathrm{m}$ using diamond grinding papers and thereafter ion milled to electron transparency using a Gatan PIPS instrument at 5 and $2 \mathrm{kV}$ accelerating voltage.

Elemental depth profiles of the as-deposited films were performed using timeof-flight elastic recoil detection analysis (ToF-ERDA). Here, a $40 \mathrm{MeV}{ }^{127} \mathrm{I}^{9+}$ beam was directed to the films at an incident angle of $67.5^{\circ}$ with respect to the surface normal, and the recoils were detected at an angle of $45^{\circ}[26,27]$. All spectra were analyzed using the CONTES code [28], where the recoil energy of each element was converted to relative atomic concentration profiles.

Mesa etching for isolation of the highly doped epitaxial top SiC layer and definition of the contact pads for the linear transmission line model measurements (TLM) was performed using a two-step inductively coupled plasma (ICP) dry etching system with a $1 \mu \mathrm{m}$ thick silicon dioxide etching mask. The TLM structures consists 
of six contact pads (100 $\mu \mathrm{m}$ wide) separated by $5,10,15,20$, and $25 \mu \mathrm{m}$. Currentvoltage (I-V) measurements were performed in air at room temperature, using a twoprobe station connected to a KEITHLEY 4200-SCS Semiconductor Characterization System.

\section{Results and discussion}

Figure 1 shows a XRD pattern from a typical Ti-Ge-C film. Except for peaks from the SiC substrate, the Ti-Ge-C film displays only $000 \ell \mathrm{Ti}_{3} \mathrm{GeC}_{2}$ reflections, consistent with peak positions reported for epitaxially grown $\mathrm{Ti}_{3} \mathrm{GeC}_{2}$ on $\mathrm{Al}_{2} \mathrm{O}_{3}(0001)$ substrates $[13,29]$. The presence of TiC in the samples cannot be excluded using XRD since the $\mathrm{SiC}(0004)$ substrate peak overlaps with the TiC(111) peak (ICDD PDF 22-1317 and 32-1383 for $\mathrm{SiC}$ and $\mathrm{TiC}$, respectively). In fact, TEM showed that trace amounts of TiC inclusions are present. The presence of only $000 \ell$ diffraction peaks shows that the $\mathrm{Ti}_{3} \mathrm{GeC}_{2}$ films are $000 \ell$-oriented on the $4 \mathrm{H}-\mathrm{SiC}(0001)$ substrate with a $4^{\circ}$ angle relative to the substrate surface, following the substrate off-cut angle. This corresponds to the growth mode for $\mathrm{Ti}_{3} \mathrm{SiC}_{2}$ on similar off-cut $4 \mathrm{H}-\mathrm{SiC}(0001)$ wafers [12]. The lattice parameters for $\mathrm{Ti}_{3} \mathrm{GeC}_{2}$ are $\mathrm{a}=3.077 \AA$ and $\mathrm{c}=17.76 \AA$ (ICDD PDF 20-0451). These values are very similar to the values for $\mathrm{Ti}_{3} \mathrm{SiC}_{2}$, where $\mathrm{a}=3.062 \AA$ and $\mathrm{c}=17.637 \AA$ (ICDD PDF 40-1132). This means that $\mathrm{Ti}_{3} \mathrm{GeC}_{2}$, just like $\mathrm{Ti}_{3} \mathrm{SiC}_{2}$, has a very small lattice mismatch, less than $0.2 \%$, of the basal planes with $4 \mathrm{H}-\mathrm{SiC}$, where $a=3.073 \AA$ and $c=10.053 \AA$ (ICDD PDF 22-1317). 
In Figure 2(a), a low magnification TEM image shows both the SiC substrate and the epitaxial $\mathrm{Ti}_{3} \mathrm{GeC}_{2}$ film grown on top. It can be seen that the $\mathrm{Ti}_{3} \mathrm{GeC}_{2}$ film growth follows the $4^{\circ}$ off-cut orientation of the $\mathrm{SiC}$ substrate surface, which is consistent with the XRD observations. Figure 2(b) shows a high-resolution image of the film, which consists predominantly of $\mathrm{Ti}_{3} \mathrm{GeC}_{2}$. Only trace amounts of $\mathrm{TiC}(111)$ inclusions in the $\mathrm{Ti}_{3} \mathrm{GeC}_{2}$ films were observed.

Figure 3 is a ToF-ERDA depth profile of a $\mathrm{Ti}_{3} \mathrm{GeC}_{2}$ sample and shows the composition to be 51 at. $\% \mathrm{Ti}, 13$ at. $\% \mathrm{Ge}$, and 36 at. $\% \mathrm{C}$ with a margin of error of less than 2 at. \%. Oxygen is only observed at the surface of the $\mathrm{Ti}_{3} \mathrm{GeC}_{2}$ films; no oxygen is found throughout the films or at the interface between the $\mathrm{Ti}_{3} \mathrm{GeC}_{2}$ and the $\mathrm{SiC}$ (below the detection limit). This is to be expected since a plasma-etching step was performed prior to deposition, in order to remove surface oxide on the $\mathrm{SiC}$ substrate [11].

The composition obtained from the ToF-ERDA depth profile deviates from a stoichiometric $\mathrm{Ti}_{3} \mathrm{GeC}_{2}$ composition. Since our films are virtually phase pure (neglecting the trace amounts of $\mathrm{TiC}_{\mathrm{x}}$ ), we conclude that our films are substoichiometric in Ge with $\mathrm{x}=0.8 \pm 0.1$ in $\mathrm{Ti}_{3} \mathrm{Ge}_{\mathrm{x}} \mathrm{C}_{2}$.

The conclusion that our films are substoichiometric in Ge is further supported by the fact that the relative peak intensities of the 0002 and 0008 peaks differ strongly from the ideal peak-intensity ratio of the stoichiometric compound, for which the 0008/0002 peak-intensity ratio is $\sim 3$ compared to $\sim 28$ for the present films. Simulations using the Carine and PowderCell softwares (not shown) show that this intensity difference is consistent with a Ge substoichiometry corresponding to an approximate composition of $\mathrm{Ti}_{3} \mathrm{Ge}_{0.8} \mathrm{C}_{2}$. Although MAX-phases are described as 
having 211, 312, or 413 stoichiometry, there exist stoichiometry ranges for vacancies at $\mathrm{A}$ and $\mathrm{X}$ sites, examples of this are $\mathrm{Ti}_{3} \mathrm{AlC}_{1.8}$ [4] and $\mathrm{Ti}_{2} \mathrm{AlC}$, where first-principles calculations have shown it to be stable for compositions as low as $\mathrm{Ti}_{2} \mathrm{Al}_{0.5} \mathrm{C}$ [30]. Few investigations on the substoichiometry of MAX-phases synthesized in bulk form have been reported. A recent publication is the work of Cabioc'h et al. where the substoichiometry and solid solution effects in $\mathrm{Ti}_{2} \mathrm{Al}\left(\mathrm{C}_{x}, \mathrm{~N}_{1-x}\right)_{y}$ compounds was investigated. In this study it was found that significant deviations from the ideal composition of MAX-phases are possible to achieve [31]. It is likely that the observed substochiometry of $\mathrm{Ti}_{3} \mathrm{GeC}_{2}$ thin films could also be achieved in bulk $\mathrm{Ti}_{3} \mathrm{GeC}_{2}$. However, this has not been studied.

Figure 4 shows SEM images of a typical $\mathrm{Ti}_{3} \mathrm{GeC}_{2}$ film. The films have a stepflow growth pattern with $\{11 \overline{2} 0\}$ step facets, where the off-cut SiC surface provides the growth steps. The topography of the $\mathrm{Ti}_{3} \mathrm{GeC}_{2}$ films was also investigated using helium ion microscopy (HIM), which has a smaller probe size and a smaller interaction volume as compared to SEM, making it possible to achieve higher surface sensitivity and image resolution $[32,33]$. Figure 5 displays a HIM image of one of the steps. The image confirms the hexagonal shape of the surface layers and reveals that what appears to be single terraces in the SEM (c.f. Figure 4) actually consists of several layers with thickness of a single crystal unit cell or fraction thereof.

AFM imaging in Figure 6 of the $\mathrm{Ti}_{3} \mathrm{GeC}_{2}$ film was used to quantify the heights of the terraces. The step heights were found to be half a unit cell, one unit cell, or multiples thereof, like with $\mathrm{AFM}$ observations made on $\mathrm{Ti}_{3} \mathrm{SiC}_{2}$ grown on $\mathrm{SiC}(0001)$ substrates [12]. For the case of $\mathrm{Ti}_{3} \mathrm{GeC}_{2}$, Figure 6 shows the presence of 
$\sim 20 \mathrm{~nm}$ large particles on the surface of the film. This was also observed during HIM imaging, and can be attributed to the segregation of Ge to the surface of the films. Surface segregation into Ge particles, several hundred nanometers in size, has been reported for $\mathrm{Ti}_{2} \mathrm{GeC}_{2}$ [15] and $\mathrm{Cr}_{2} \mathrm{GeC}$ magnetron-sputtered thin films, and has been attributed to fast Ge-diffusion rates along the basal planes [19]. The out-diffusion of group-14 A elements in Ti-A-C MAX phases has been studied by Emmerlich et al., where no surface segregation was found for $\mathrm{Ti}_{3} \mathrm{SiC}_{2}$, while $\mathrm{Ti}_{2} \mathrm{GeC}$ and $\mathrm{Ti}_{2} \mathrm{SnC}$ had extensive surface segregations [15]. Since our films are substoichiometric in Ge, the supersaturation conditions required for formation of large islands are most likely not fulfilled. Therefore, small Ge particles (on the order of $20 \mathrm{~nm}$ ), evenly distributed on the terraces, are formed rather than the larger Ge islands seen in Refs. [15] and [19].

The growth mode of the $\mathrm{Ti}_{3} \mathrm{GeC}_{2}$ films is similar to the step-flow growth that we have recently reported for the epitaxial growth of $\mathrm{Ti}_{3} \mathrm{SiC}_{2}$ films on $4 \mathrm{H}-\mathrm{SiC}(0001)$ [12]. An interesting difference is that for the $\mathrm{Ti}_{3} \mathrm{SiC}_{2}$ films, $\mathrm{Si}$-supersaturation growth conditions were necessary to maintain equilibrium-shape, hexagonal steps. The $\mathrm{Ti}_{3} \mathrm{GeC}_{2}$ films, however, grow with hexagonal steps for depositions made with the same growth conditions, which for $\mathrm{Ti}_{3} \mathrm{SiC}_{2}$ lead to $\left\{\begin{array}{lll}1 \overline{1} & 0 & 0\end{array}\right\}$ terrace edge truncation. The observations of equilibrium shape steps and the formation of Ge particles indicate that $\mathrm{Ti}_{3} \mathrm{GeC}_{2}$ is at equilibrium at a substoichiometric composition unlike $\mathrm{Ti}_{3} \mathrm{SiC}_{2}$, which requires supersaturation for nucleation and growth.

In order to study the possible application of the epitaxially grown $\mathrm{Ti}_{3} \mathrm{GeC}_{2}$ films as ohmic contacts to $4 \mathrm{H}-\mathrm{SiC}$, current-voltage (I-V) measurements were performed on TLM contact pads. The definition of an ohmic contact is that its 
current-voltage (I-V) curve is linear and symmetric. Figure 7 shows I-V curves measured on two neighboring contact pads with a $5 \mu \mathrm{m}$ separation. As can be seen from the I-V curves the $\mathrm{Ti}_{3} \mathrm{GeC}_{2}$ displays an almost ohmic behavior. Applying a hightemperature rapid thermal anneal might help achieve low-resistivity ohmic contacts to $\mathrm{SiC}$, as seen for epitaxial $\mathrm{Ti}_{3} \mathrm{SiC}_{2}$ films after high temperature annealing at $950{ }^{\circ} \mathrm{C}$ [11].

\section{Conclusions}

We have grown epitaxial $\mathrm{Ti}_{3} \mathrm{GeC}_{2}$ thin films with substoichiometry in $\mathrm{Ge}$ on $4^{\circ}$ offcut $4 \mathrm{H}-\mathrm{SiC}(0001)$ substrates using DC magnetron sputtering from three separate targets. The growth mode of the $\mathrm{Ti}_{3} \mathrm{GeC}_{2}$ layers is lateral step-flow on (0001) terraces

and with $\{11 \overline{2} 0\}$ step faceting. This differs from $\mathrm{Ti}_{3} \mathrm{SiC}_{2}$ where Si-supersaturation conditions were necessary to achieve the hexagonal growth pattern. Finally, $\mathrm{Ti}_{3} \mathrm{GeC}_{2}$ films display an almost ohmic behavior with only self-annealing from the growth at $800{ }^{\circ} \mathrm{C}$.

\section{Acknowledgements}

Funding from the VINN Excellence Center in Research and Innovation on Functional Nanoscale Materials (FunMat) by the Swedish Governmental Agency for Innovation 
Systems (VINNOVA) is acknowledged. We thank the staff at the Tandem Laboratory, Uppsala University for support during the ERD analysis. 


\section{References}

[1] M.W. Barsoum, T. El-Raghy, J. Amer. Cer. Soc. 79 (1996) 1953.

[2] M.W. Barsoum, D. Brodkin, T. El-Raghy, Scr. Mater. 36 (1997) 535.

[3] M.W. Barsoum, Prog. Solid State Chem. 28 (2000) 201.

[4] P. Eklund, M. Beckers, U. Jansson, H. Högberg, L. Hultman, Thin Solid Films 518 (2010) 1851

[5] Z.M. Sun, Int. Mater. Rev. 56 (2011) 143.

[6] F. Goesmann, R. Schmid-Fetzer, Semicond. Sci. Technol. 10 (1995) 1652.

[7] Z. Wang, S. Tsukimoto, M. Saito, K. Ito, M. Murakami, Y. Ikuhara, Phys. Rev. B: Condens. Matter. 80 (2009) 245303.

[8] S. Tsukimoto, K. Ito, Z. Wang, M. Saito, Y. Ikuhara, M. Murakami, Mater. Trans. 50 (2009) 1071.

[9] B. Pécz, L. Tóth, M.A. di Forte-Poisson, J. Vacas, Appl. Surf. Sci. 206 (2003) 8.

[10] F. La Via, F. Roccaforte, A. Makhtari, V. Raineri, P. Musumeci, L. Calcagno, Microelectron. Eng. 60 (2002) 269.

[11] K. Buchholt, R. Ghandi, M. Domeij, C.-M Zetterling, J. Lu, P. Eklund, L. Hultman, A. Lloyd Spetz, Appl. Phys. Lett. 98 (2011) 042108.

[12] K. Buchholt, P. Eklund, J. Jensen, J. Lu, A. Lloyd Spetz, L. Hultman, Scr. Mater. 64 (2011) 1141.

[13] H. Högberg, P. Eklund, J. Emmerlich, J. Birch, L. Hultman, J. Mater. Res. 20 (2005) 779. 
[14] T.H. Scabarozi, P. Eklund, J. Emmerlich, H. Högberg, T. Meehan, P. Finkel, M.W. Barsoum, J.D. Hettinger, L. Hultman, S.E. Lofland, Solid State Commun. 146 (2008) 498.

[15] J. Emmerlich, P. Eklund, D. Rittrich, H. Högberg, L. Hultman, J. Mater. Res. 22 (2007) 2279.

[16] T. El-Raghy, S. Chakraborty, M.W. Barsoum, J. Eur. Ceram. Soc. 20 (2000) 2619.

[17] S.E. Lofland, J.D. Hettinger, K. Harrell, P.Finkel, S. Gupta, M.W. Barsoum, G. Hug, Appl. Phys. Lett. 84 (2004) 508.

[18] O. Wilhelmsson, P. Eklund, H. Högberg, L. Hultman, U. Jansson, Acta Mater. 56 (2008) 2563.

[19] P. Eklund, M. Bugnet, V. Mauchamp, S. Dubois, C. Tromas, J. Jensen, L. Piraux, L. Gence, M. Jaouen, T. Cabioc’h, Phys. Rev. B 84 (2011) 075424.

[20] S. Kerdsongpanya, K. Buchholt, O. Tengstrand, J. Lu, J. Jensen, L. Hultman, P. Eklund, J. Appl. Phys. 110 (2011) 053516.

[21] T.H. Scabarozi, S. Benjamin, B. Adamson, J. Applegate, J. Roche, E. Pfeiffer, C. Steinmetz, C. Lunk, M.W. Barsoum, J.D. Hettinger, S.E. Lofland, Scr. Mater. 66 (2012) 85

[22] N.J. Lane, S.C. Vogel, M.W. Barsoum, Phys. Rev. B 82 (2010) 174109.

[23] SiCrystal AG, Guenther-Scharowsky-Str.1, D91058 Erlangen, Germany.

[24] Acreo AB, Electrum 239, 16440 Kista, Sweden.

[25] J. Emmerlich, H. Högberg, S. Sasvári, P. O. Å. Persson, L. Hultman, J. P. Palmquist, U. Jansson, J.M. Molina-Aldareguia, Z. Czigány, J. Appl. Phys. 96 (2004) 4817. 
[26] H. J. Whitlow, G. Possnert, C.S. Petersson, Nucl. Instrum. Methods B. 27 (1987) 448 .

[27] J. Jensen, D. Martin, A. Surpi, T. Kubart, Nucl. Instrum. Methods B. 268 (2010) 1893.

[28] M.S. Janson, CONTES Instruction Manual, Internal Report, Uppsala University, 2004.

[29] H. Högberg, L. Hultman, J. Emmerlich, T. Joelsson, P. Eklund, J.M. MolinaAldareguia, J.-P. Palmquist, O. Wilhelmsson, U. Jansson, Surf. Coat. Technol. $193(2005) 6$.

[30] J. Wang, Y. Zhou, T. Liao, J. Zhang, Z. Lin, Scr. Mater. 58 (2008) 227.

[31] T. Cabioc'h, P. Eklund, V. Mauchamp, M. Jaouen, Accepted for publication in Journal of the European Ceramic Society.

[32] D. Cohen-Tanugi, N. Yao, J. Appl. Phys. 104 (2008) 063504.

[33] B.W. Ward, J.A. Notte, N.P. Economou, J. Vac. Sci. Technol. B 24 (2006) 2871. 


\section{FIGURES}

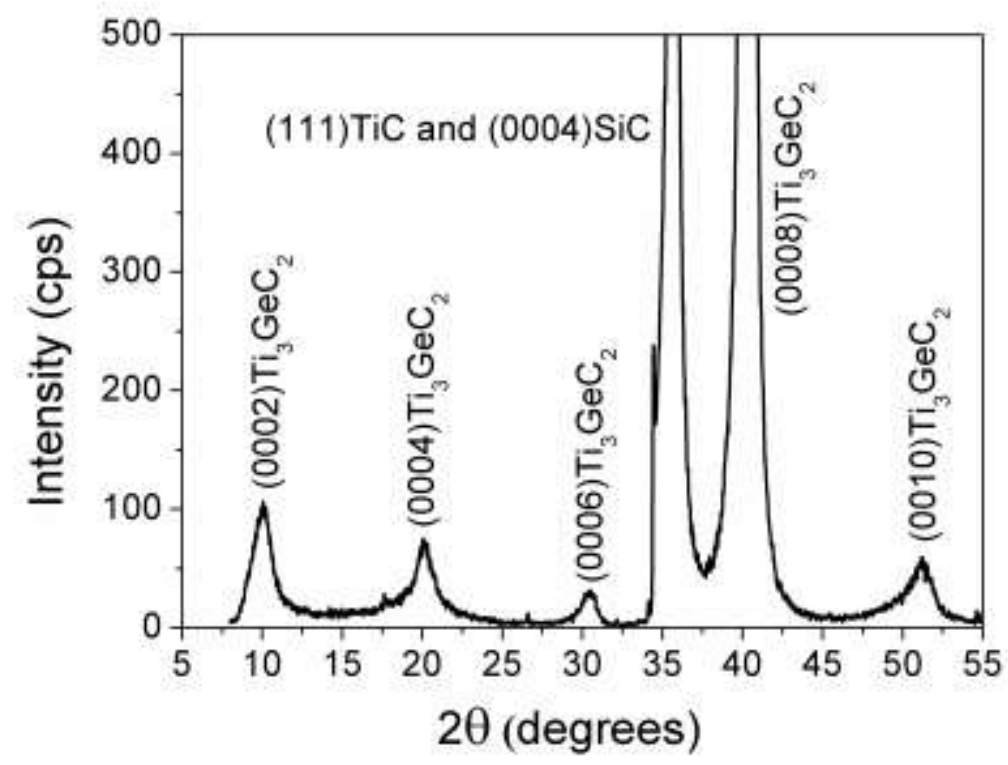

Figure $1 \mathrm{XRD}$ pattern from a $\mathrm{Ti}_{3} \mathrm{GeC}_{2}$ film. 
a
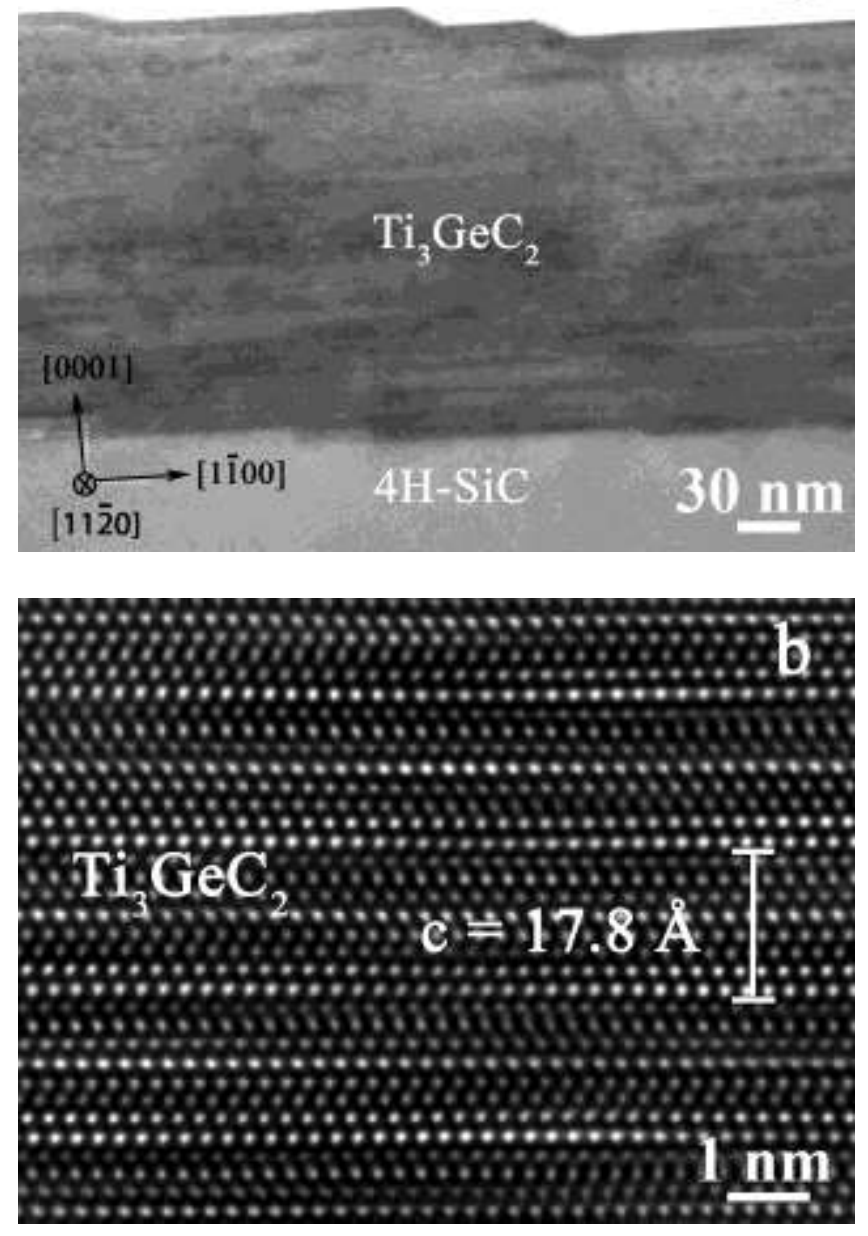

Figure 2 TEM image of a $\mathrm{Ti}_{3} \mathrm{GeC}_{2}$ film at (a) low, and (b) high magnification. 


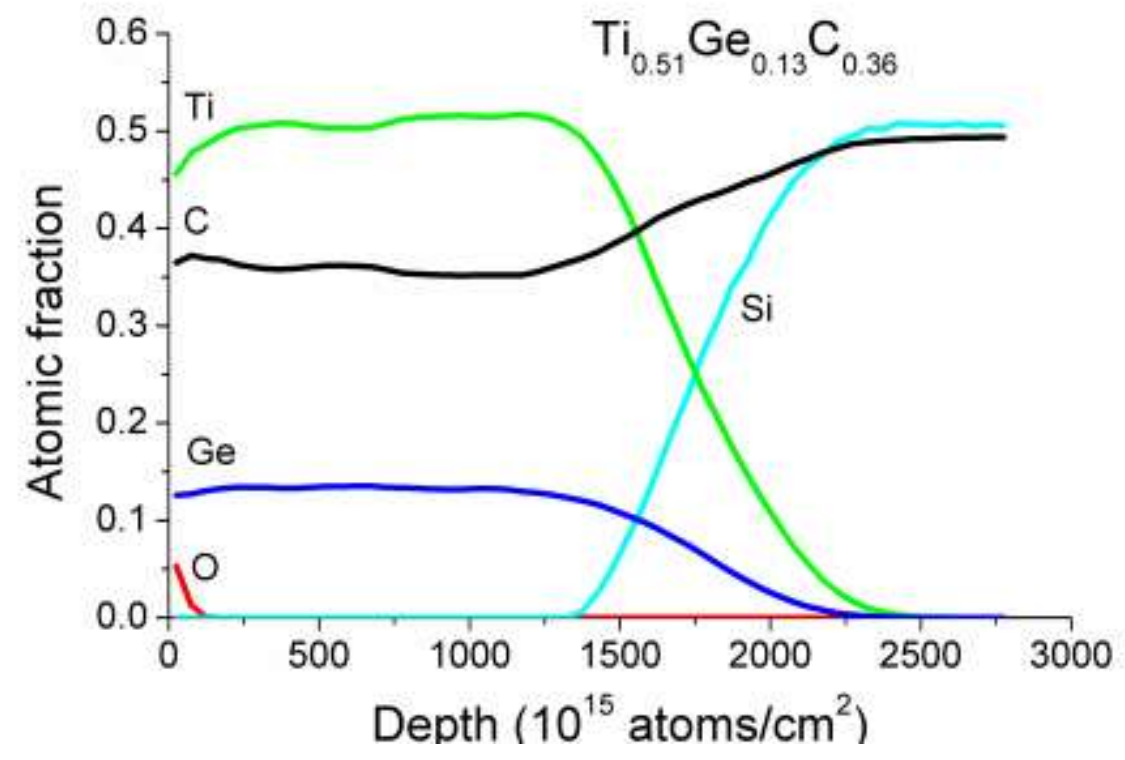

Figure 3 ToF-ERDA depth profile of a $\mathrm{Ti}_{3} \mathrm{GeC}_{2}$ film. 


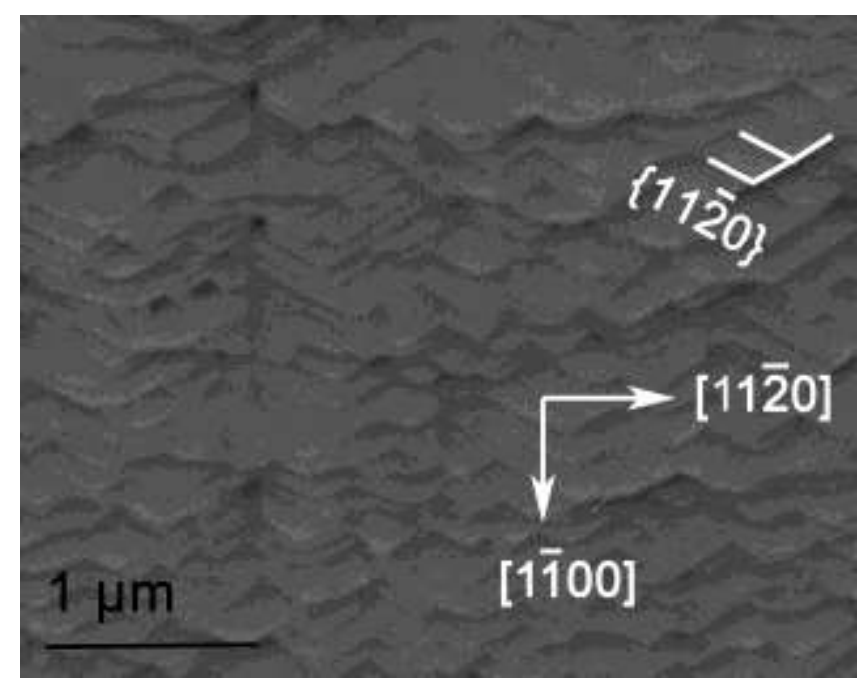

Figure 4 SEM image of a $\mathrm{Ti}_{3} \mathrm{GeC}_{2}$ film. Arrows indicate the $\mathrm{SiC}$ substrate crystal directions. $\mathrm{Ti}_{3} \mathrm{GeC}_{2}\{11 \overline{2} 0\}$ step facets are also indicated. 


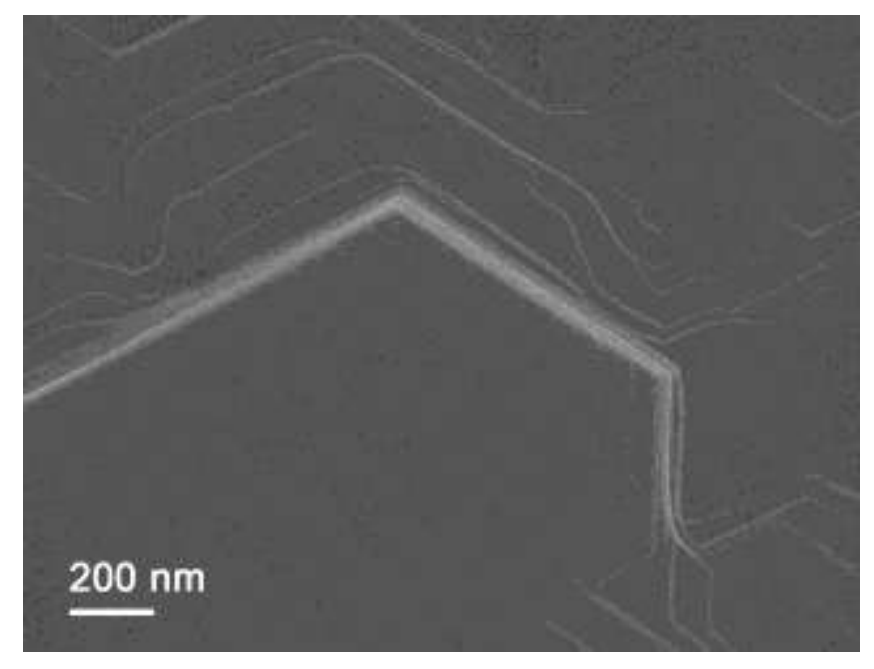

Figure 5 HIM image of a $\mathrm{Ti}_{3} \mathrm{GeC}_{2}$ film. 


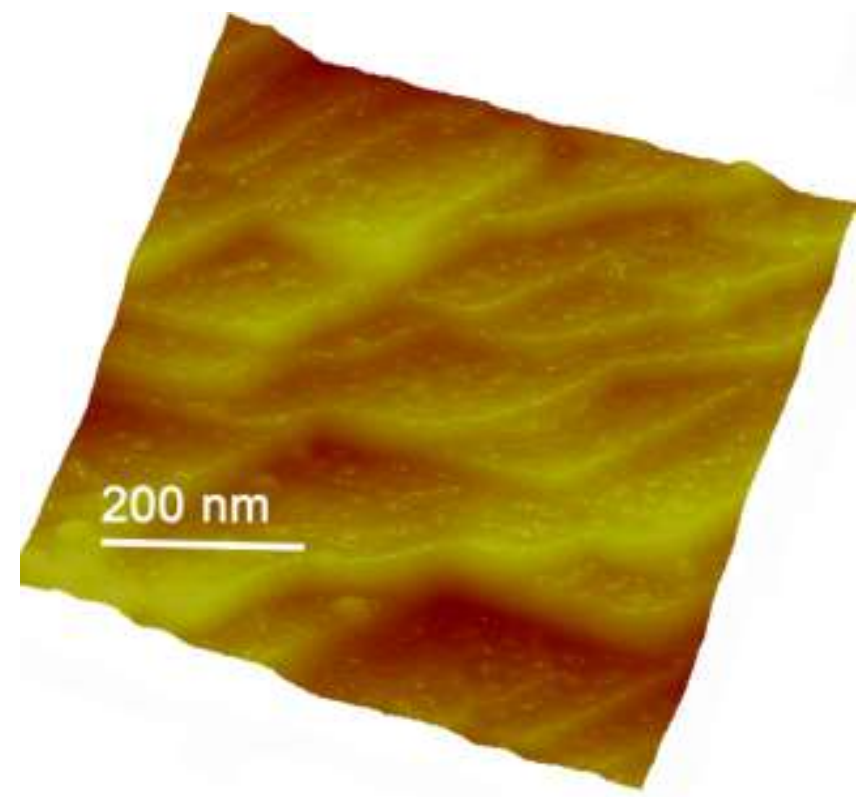

Figure 6 AFM surface plot of a $\mathrm{Ti}_{3} \mathrm{GeC}_{2}$ film. 


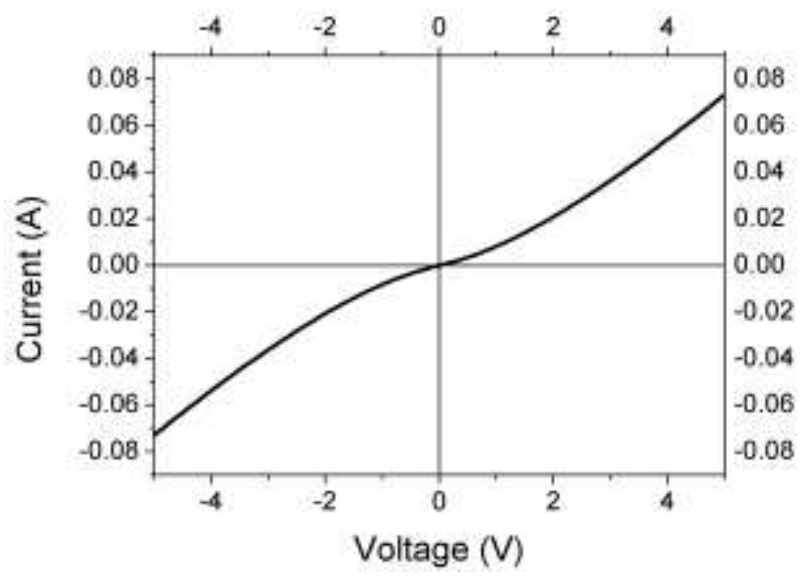

Figure $7 \mathrm{I}-\mathrm{V}$ curve from two neighboring $\mathrm{Ti}_{3} \mathrm{GeC}_{2}$ film contact pads on n- type $4 \mathrm{H}-$ $\mathrm{SiC}$. 